\title{
The Economics of Exchange Rates: A South African Model
}

\section{S Brink and R Koekemoer}

Department of Economics, University of Pretoria

\begin{abstract}
This paper attempts to capture the determination of the South African exchange rate in a theoretically plausible model with reliable forecasting ability. A stickyprice, Dombusch-type monetary model of the rand/dollar exchange rate is proposed. The three-step Engle and Yoo cointegration procedure is applied and the test results indicate that the nominal exchange rate is cointegrated with relative real output, the relative money supplies and the inflation differential. An error correction model is estimated and shocks are applied to each of the long-run variables. Some policy implications are derived from these sensitivity tests. Finally, a fundamental equilibrium exchange rate (FEER) for the rand/dollar rate is defined and the FEER values are estimated until the year 2000 .

JEL C 51, F 31
\end{abstract}

\section{INTRODUCTION}

The South African currency unit (the rand) has for some years been sensitized both politically and with respect to other fundamentals. As a result, fluctuations tend to be more than moderate and, in some cases, in an unexpected direction. The openness of the economy is one of the vehicles of growth, employment and an equitable distribution of income and wealth in the much-publicized macroeconomic strategy of the government, where a stable exchange rate, or at least a less unpredictable one, is a prerequisite for a successful outward policy. In short, it is essential to make sense of the propellants of the exchange rate.

Attempts to model the South African exchange rate have, despite its importance for the outcome of the above-mentioned macroeconomic strategy and unlike its major counterparts (e.g. the dollar/pound rate or the Deutsche mark/pound rate), been surprisingly few and generally not very successful. In this paper, a model of the rand/dollar exchange rate is proposed. It conforms to the sticky-price Dombusch version of the monetary model, and therefore belongs to the assetapproach class of models. 
The validity of the monetary approach to exchange rate determination has been frequently questioned, due to the lack of empirical support reported by most researchers in the field. Irrespective of whether the monetary model's empirical failure stems from inadequate statistical techniques or fundamentally flawed theoretical content, its application to the South African exchange rate model requires some justification. In an effort to provide this, the asset-market approach to exchange rate determination, to which the monetary approach belongs, is briefly recapitulated below to illustrate the absence of clear alternatives. Some perspectives on the empirical status of the monetary model and an elaboration of the version used in the rand/dollar model then follow. After that, the rand/dollar exchange rate is modelled, using the three-step Engle and Yoo cointegration technique and reporting the results thereof. Finally, some relevant policy implications are considered and a fundamental equilibrium exchange rate (FEER) is proposed, given certain criteria for internal and external equilibrium.

\section{SELECTING THE THEORETICAL FOUNDATION: THE ASSET APPROACH RECAPPED}

Markets for foreign exchange came to be viewed as asset markets during the latter half of the 1970s. The asset approach may be contrasted with the traditional flow approaches, in the sense that the latter allows shocks to affect trade flows via shifts in the terms of trade or an altered relationship between domestic absorption and output. An expansionary monetary or fiscal policy, for example, will therefore raise the demand for imports and consequently for the foreign currency, depreciating the domestic currency. Conversely, an improvement in the current account in the flow model signifies an appreciation of the exchange rate.

The contrasting "asset" models do not assign adjustments in the relative prices of goods more than a fairly minor supporting role. The asset approach models commonly view the exchange rate as the foreign currency price that equilibrates the net stock demands for financial assets denominated in different currencies (Frankel, 1980: 1). In principle, the two modelling strategies can be synthesized. The exchange rate would then be viewed as equilibrating the total demand for and supply of foreign currency, with complete integration of the current and capital accounts of the balance of payments. In this case, flows should be consistent with the corresponding asset stock requirements. Most research has, however, emphasized one approach at the expense of the other, and since the advent of the 1973 float the asset-market view has become dominant.

Asset-market models have occupied most of what has been written on exchange rates for the past 25 years. Rather than elaborating on the contrast between the 
traditional flow models and the asset approach models, distinguishing between the different asset-market models may prove useful for the purpose of this study. The monetary approach to exchange rate determination ranks prominently among the latter class of models: Virtually all the considerable number of models developed since 1973 to clarify the volatility of floating rates, feature an adjustment process that assigns the equilibration of national money markets a prominent role.

The monetary approach undoubtedly falls short of an adequate explanation of the observed volatility in major currencies. However, consensus suggests that better results would not be obtained by disregarding financial market implications. Stress should primarily fall on an improved specification of asset-market models (Boughton, 1988: 2).

Non-monetary asset models are collectively referred to as portfolio-balance models. All the asset-market (i.e. monetary and non-monetary) models share the perfect capital mobility assumption. That is, the absence of substantial transactions costs, capital controls, or any other constraints on the flow of capital between countries is implied. Exchange rates thus adjust instantly, with the empirical implication that they may exhibit a degree of variability exceeding that of their underlying determinants (Frankel, 1980:1).

The taxonomy of asset-market models establishes a particular dichotomy according to which the monetary and portfolio balance models are distinguished: If domestic and foreign bonds are regarded as perfect substitutes, portfolio shares become infinitely sensitive to expected rates of return and bond supplies become irrelevant. Determination of the exchange rate then shifts towards the money markets (op. cit.: 4).

In the non-monetary or portfolio balance class of asset-market models, the perfect substitutability assumption is relaxed and asset holders allocate their portfolios across shares that are well-defined functions of expected rates of return (op. cit.: 4). The perfect mobility of capital assumption is retained and a distinction between perfect mobility and perfect substitutability can evidently be drawn: The first implies the absence of impediments to capital flows whereas the second is the much stronger assumption that asset holders are indifferent as to the composition of their bond portfolios, provided that the expected rate of return on the two countries' bonds is identical when converted to a common numeraire (op. cit.: 2).

The portfolio balance model is considered to be the most general model of exchange rate determination. Its empirical validity is, however, flawed on two counts: A test of the complete model is close to impossible given the 
unavailability of appropriate data and, in truncated form, it generates poor results, even for the early period of the 1973 float. Although there can be little doubt that a suitable exchange rate model should reflect the asset-market approach as opposed to the traditional flow approaches, the portfolio balance model is not a natural choice on account of data considerations. In early versions of the rand/dollar model presented in this paper, first, a portfolio balance approach and, later, a hybrid model of the monetary and portfolio balance approaches were followed. In both cases, substantial difficulty was encountered in assembling the data, and the test results were unsatisfactory.

Instead, a simple monetary model is proposed for and adapted to South African circumstances. Given the empirical shortcomings of the monetary model, the selection of the monetary approach as a basis for the rand/dollar rate needs some justification: The monetary model is generally regarded as the "standard workhorse" in intemational finance (Frankel \& Rose, 1994: 3). In addition, the monetary model provides a useful tool for exchange rate analysis because it, firstly, clearly defines the role of speculation among the exchange rate determinants and, secondly, gives a simple definition of the equilibrium exchange rate. Moreover, it directly relates the equilibrium rate to the underlying instruments of monetary policy (Bilson, 1978; 48). Most importantly, an obvious alternative is clearly lacking.

The sticky-price Dornbusch model of the rand/dollar rate yielded unexpectedly good results for the sample period. The rand/dollar model, which closely resembles the "standard workhorse" variant of the monetary model, was adjusted in earlier attempts to improve empirical results. Current account data was introduced to obtain a variant similar to the Hooper-Morton model. Also, attempts were made to capture Driskill's imperfect substitutability assumption or, alternatively, to specify a hybrid monetary-portfolio balance model. Finally, variables similar to those proposed by Throop (1993) were introduced - without success. These variables included the budget deficit, the price of oil and a gold price/oil price terms-of-trade type of variable. All the attempts to find a better model proved fruitless or were prematurely frustrated by the unavailability of data. As a result, the "standard workhorse" variant of the monetary model was retained.

Ideally, a truly sophisticated exchange rate model should accommodate forwardlooking expectations. Rational expectations with time-invariate parameters as embodied in the efficient market hypothesis, may be introduced. The rand/dollar model implicitly contains rational expectations in the sense that expected future values are assumed to materialize. Expected future values therefore equal actual future values. Alternatively, expectations with time-variate parameters, as embodied in the learning models, may be introduced. Although plausible, a 
leaming model was not simulated in this study due to technical constraints, but will be pursued in future research. Regrettably, an intertemporal optimizing model was also excluded from the empirical work, as it requires an approach with strong micro foundations, which is beyond the scope of this study. The focus of this study is mainly on a simple, structural long-run macro-model. As with learning, intertemporal optimization will undoubtedly receive the attention it deserves in future empirical work on the South African exchange rate.

EMPIRICAL STATUS OF THE MONETARY MODEL

Friedman (1953: 158) in his argument for flexible exchange rates, stated that: "The ultimate objective is a world in which exchange rates, while free to vary, are in fact highly stable: Instability of exchange rates is a symptom of instability in the underlying economic structure". The monetary model, as part of the asset approach, was induced by the failure of the traditional trade-flow models, to define the elements of the "underlying economic structure" that have been responsible for the erratic exchange rate movements. It may be said that the monetary approach has for the past two decades become the standard point of departure for the literature on exchange rate determination. Admittedly, the monetary approach fails to provide an adequate explanation of the movements in major currency values during the floating-rate period that commenced in 1973. The causes of this failure will be subsequently examined.

After initial claims of success (the so-called first-period tests for the present float prior to 1978), the empirical failure of a simple monetary model with flexible prices became apparent (Frankel and Rose, 1994: 5). The coefficient estimates and empirical fit of such models were less than reassuring, with the possible exception of hyperinflation conditions. In addition, the observed volatility of real exchange rates and the highly positive correlation of nominal and real exchange rates became obvious enough to warrant explicit treatment (op. cit.: 6). Moreover, the models forecasted poorly out-of-sample. The apparent contradiction of the assumption of flexible prices emerging from these findings, naturally led to the assumption of sticky prices.

The essence of the sticky-price overshooting, or Dornbusch model is captured in a simple, yet strong, statement that proportionality exists between the real exchange rate and the contemporaneous real interest differential (op. cit:: 8). Early tests of the overshooting model focussed on more complete models than the simple proportionality between the real exchange rate and the real interest differential. Such tests of exchange rate models with sticky prices met with initial success, but eventually fell apart both in and out-of-sample (op. cit:: 11). The emphasis has subsequently shifted to subjecting the simple testable result of 
the model relating the real exchange rate to the contemporaneous real interest differential to increasingly sophisticated time-series econometrics. Meese and Rogoff (1988) applied the Engle-Granger test for cointegration and found no evidence of such a relationship. Similarly, Campbell and Clarida (1987) reported a lack of supporting evidence.

It has been noted that the poor results could be attributed either to the existence of a missing variable or, alternatively, the weak power in the tests (Frankel and Rose, 1994: 11). Subsequent studies employed increasingly powerful econometric procedures (such as the Johansen procedure) and included other variables. For example, evidence of cointegration between the real exchange rate and real interest differential was reported after the incorporation of a measure of the cumulated current account ( $o p$. cit: 12). Strong results were reported in a subsequent study by Throop (1993), after allowance for several other variables has been made: A lagged effect of the real interest differential, the budget deficit, the real price of oil and a measure of the relative price of non-traded goods.

\section{DEVELOPING THE MONETARY EQUATION}

A general statement of the monetary approach comprises five hypotheses:

1. Purchasing power parity (PPP) holds over some time horizon.

2. Uncovered interest parity (UIP) holds at all times.

3. The demand for real money balances is a stable function of a small set of real variables.

4. The supply of money is determined by a stable process.

5. Expectations are (in some sense) rational (Boughton, 1988:4).

The joint hypotheses of PPP in the long run and UIP at all times call for some remarks. The relative version of PPP can be written in its ex ante expectational form as:

$$
\varepsilon(d e)=\varepsilon(d p)-\varepsilon\left(d p_{f}\right)
$$

with $\varepsilon(d e)$ the $\log$ of the expected depreciation in the domestic currency, $\varepsilon(d p)$ the $\log$ of the the expected domestic inflation rate and $a d p d$ the $\log$ of the expected foreign inflation rate. Equation (1) states that the expected exchange rate depreciation equals the expected inflation differential. UIP states that the expected depreciation is equal to the interest differential:

$$
\varepsilon(d e)=i-i_{j}
$$


Equations (1) and (2) can now be rewritten and combined to establish ex ante real interest parity (RIP):

$$
\varepsilon-a_{f}=[i-\varepsilon(d p)]-\left[i_{f}-\varepsilon\left(d p_{f}\right)\right]
$$

with $r$ denoting the real interest rate. Equation (3) states that RIP holds if both PPP and UIP hold. The joint hypothesis of PPP and UIP therefore also imply the rather strong hypothesis of RIP. As deviations from PPP are assumed not to occur in the long run and such deviations are generally caused by exchange rate or inflation forecast errors, such errors are assumed not to exist. In addition, deviations from UIP caused by risk premia or exchange rate forecast errors are assumed to be absent. The first two hypotheses in the list above should therefore be recognized as the stringent assumptions that they are: Simultaneous PPP, UIP and RIP are implied and all sources of deviation from any of these parity conditions are assumed not to exist (Marston, 1997: 289).

The fundamental equation in the monetary approach is a conventional money demand function:

$$
m=p+\phi y-\lambda i
$$

where $m \equiv$ the $\log$ of the domestic money supply, $p \equiv$ the $\log$ of the domestic price level, $y \equiv$ the log of domestic real income, $i \equiv$ the nominal domestic short term interest rate, $\phi \equiv$ the income elasticity of the demand for money and $\lambda \equiv$ the interest rate semi-elasticity of the demand for money.

A similar money demand function is formulated for the foreign country:

$$
m_{f}=p_{f}+\phi y_{f}-\lambda_{i f}
$$

A relative money demand function is obtained by subtracting equation (5) from equation (4):

$$
\left(m-m_{f}\right)=\left(p-p_{f}\right)+\phi\left(y-y_{f}\right)-\lambda\left(i-i_{f}\right)
$$

Uncovered interest parity is implied by the perfect substitutability or single-bond assumption:

$$
i-i_{f}=\varepsilon(d e)
$$

where a(de) represents the expected depreciation of the domestic currency.

The relative price level can be obtained by rewriting equation (6):

$$
\left(p-p_{f}\right)=\left(m-m_{f}\right)-\phi\left(y-y_{f}\right)+\lambda\left(i-i_{f}\right) \text {. }
$$

Equations (7) and (8) are subsequently combined:

$$
\left(p-p_{f}\right)=\left(m-m_{f}\right)-\phi\left(y-y_{f}\right)+\lambda \varepsilon(d e)
$$


Equation (9) states that relative prices are determined by the domestic money supply relative to the foreign money supply, domestic income relative to foreign income and also by the expected depreciation in the domestic currency.

A long-run version of PPP is now introduced:

$$
\bar{e}=\bar{p} \cdot \overline{p_{f}}
$$

with the bars over the variables signifying long-run relationships and $e \equiv$ the $\log$ of the spot exchange rate, reflecting the domestic price of foreign currency. Equation (9) can be combined with (10) and rewritten as:

$$
\bar{e}=\left(\bar{m}-\overline{m_{f}}\right)-\phi\left(\bar{y}-\bar{y}_{f}\right)+\lambda \varepsilon \overline{(d e)}
$$

In its expectational form, PPP equals the expected depreciation to the expected inflation differential:

$$
\overline{\varepsilon(d e)}=\overline{\varepsilon(d p)}-\overline{\varepsilon\left(d p_{f}\right)}
$$

A long-run version of exchange rate determination can now be obtained by combining equations (11) and (12):

$$
\bar{e}=\left(\bar{m}-\bar{m}_{f}\right)-\phi\left(\bar{y}-\bar{y}_{f}\right)+\lambda \overline{(\varepsilon(d p)}-\overline{\varepsilon\left(d p_{f}\right)}
$$

Equation (13) states that, in the long run, the exchange rate as the relative price of currency, is determined by the relative supply of and demand for money. If the domestic money supply expands, a proportionate depreciation results. Similarly, an increase in domestic income or a decline in the expected inflation rate, stimulates the demand for domestic money and results in an appreciation.

It is assumed that expectations are rational, that the system is stable, that income growth is exogenous (or random with mean zero) and, finally, that monetary growth follows a random walk as a benchmark specification. The expected inflation rates, domestic and foreign, are consequently replaced by the actual rates, to render the final form of the exchange rate equation:

$$
\bar{e}=\left(\bar{m}-\bar{m}_{f}\right)-\phi\left(\bar{y}-\bar{y}_{f}\right)+\lambda\left(\bar{\Pi}-\bar{\Pi}_{f}\right)
$$

with $\Pi$ denoting the actual inflation rate. The long-run exchange rate is therefore determined by relative money supplies, relative income levels and relative inflation rates.

Short-term deviations from PPP may occur, resulting in deviations from RIP. A real interest differential (RID) could arise as follows: 
Short-run adjustments (depreciation) towards the long-run equilibrium exchange rate are assumed to take place at a rate $\theta$ :

$$
\varepsilon(d e)=-\theta(e-\bar{e})
$$

while the long-run depreciation is reflected by relative PPP:

$$
\varepsilon(d e)=\left(\Pi-\Pi_{f}\right)
$$

Combining equation (15) with (7), UIP, and then with equation (16) results in a rate of adjustment proportional to the real interest differential:

$$
e-\bar{e}=-\frac{l}{\theta}\left[(i-\Pi)-\left(i_{f}-\Pi_{f}\right)\right]
$$

It is important to note that a real interest differential could only arise from deviations from either PPP or UIP or both. Deviations from UIP over any time horizon are ruled out by the hypotheses; while deviations from PPP are provided for only in the short run. It therefore follows that the only deviation from these parity conditions accommodated in this model, is a short-run deviation from PPP which will result in a short-run deviation from RIP. Equation (17) may then be said to capture the short-run deviations from parity conditions and thus the shortrun overshooting of the exchange rate.

A general equation of exchange rate determination may be expressed as:

$$
e=\left(m-m_{f}\right)-\phi\left(y-y_{f}\right)+\lambda\left(\Pi-\Pi_{f}\right)-\frac{1}{\theta}\left[(i-\Pi)-\left(i_{f}-\Pi_{f}\right)\right]
$$

with the last term, RID, signifying short-term overshooting. In the long run, however, all of PPP, UIP and RIP are observed and this term will become zero, indicating that overshooting in the long run is ruled out.

\section{THE STICKY-PRICE, DORNBUSCH MODEL OF THE RAND/DOLLAR EXCHANGE RATE}

\subsection{The theoretical model}

The theoretical model of the rand/dollar exchange rate is representative of the Dornbusch, sticky-price class of models. The specification includes the following variables:

$\mathrm{EXCH}=\mathrm{f}(\mathrm{M} 3, \mathrm{GDP}, \mathrm{INFL})$

$$
(+-+)
$$

with $\mathrm{EXCH}=\mathrm{LN}($ the spot exchange rate in rand/dollar) 


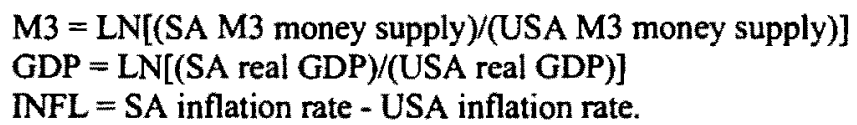

The specification corresponds to the long-run version of the Dornbusch model (equation (13) above), except that the inflation differential is substituted for the differential between the expected rates of price changes.

The spot rand/dollar exchange rate therefore depreciates (EXCH increases) if South Africa's monetary discipline becomes slack in comparison to monetary discipline in the US. Likewise, if the increase in the CPI accelerates domestic prices compared to the US, EXCH rises, signalling a depreciation in the dollar value of the rand. Economic growth may again effect an exchange rate appreciation, provided the domestic expansion of the GDP exceeds that of its foreign counterpart.

\subsection{The data}

All South African data were taken from the Quarterly Bulletin of the South African Reserve Bank. The Consumer Price Index (CPI) was used to calculate the inflation rate. The 3-month bankers' acceptance rate was considered the representative short-term interest rate, which was deflated and subsequently featured in the error correction model (ECM), to be discussed below.

The International Financial Statistics of the International Monetary Fund was the source for data on the United States. The 3-month Treasury Bill Rate represents the short-term US interest rate and appears in the ECM, after the US inflation rate was deducted, as the real short-term interest rate.

The sample period commences in 1979 , despite the ready availability of earlier data, and is decidedly shorter than what would be ideal. The reason for this is that South Africa maintained some form of fixed exchange rate system even after the demise of the Bretton Woods system until 1979. It was only from 1979 onwards that the exchange rate was permitted to float. A structural break thus manifested itself in 1979, and it appeared meaningful to restrict the sample period to the era of floating.

Although all relevant data for 1996 were available, 1995 was taken as the cut-off date of the sample period. It appears that 1996 was by no means an ordinary year for South Africa's foreign exchange markets. Unsubstantiated rumours of an overvalued currency triggered speculative sales resulting in a capital outflow and a sharp depreciation in the rand during February 1996. In addition, a mild subsequent recovery during March was rapidly reversed into a second run on the 
rand in April, when balance of payments difficulties became apparent. As a result, the rand lost 20,6 per cent of its dollar value during the first four months of 1996. An exchange rate model comprising the fundamentals of exchange rate determination loses most of its explanatory power on such occasions as the 1996 currency crisis, when negative psychology prevails. The years 1997 and 1998 were no more normal in the sense that the exchange rate failed to stabilize and continued to be dominated by non-fundamentals. It is hoped that in future, with the benefit of hindsight, sense can be made of this interlude. An explanatory list of all the variables included in the long-run cointegration relationship and the ECM is presented in Table 1:

Table $1 \quad$ List of variables

\begin{tabular}{|l|l|}
\hline EXCH & LN(Spot rand/dollar exchange rate) \\
\hline M3 & LN(Relative M3 money supply) \\
\hline GDP & LN(Relative real GDP) \\
\hline INFL & Inflation differential \\
\hline RS & Real short-term interest differential \\
\hline DUM & Dummy variable $=1$ in 1990,1991 and 1992 \\
\hline
\end{tabular}

Tests for stationarity were subsequently performed. Data plots for EXCH, GDP, M3, INFL and RS respectively (see Figure 1) indicate that EXCH and $M 3$ show definite upward trends. A similar trend in INFL is less conspicuous, although the Augmented Dickey-Fuller test results (see Table 2) unambiguously indicate that it is integrated of order 1 . The variable RS tests potentially stationary. Inspection of its data plot reveals a slightly upward trend, with what appears to be a structural break in 1986. Incidentally, a similar break is observed in the INFL series in 1986. 
Figure 1 Data plots for EXCH, GDP, M3, INFL and RS: 1979 - 1995

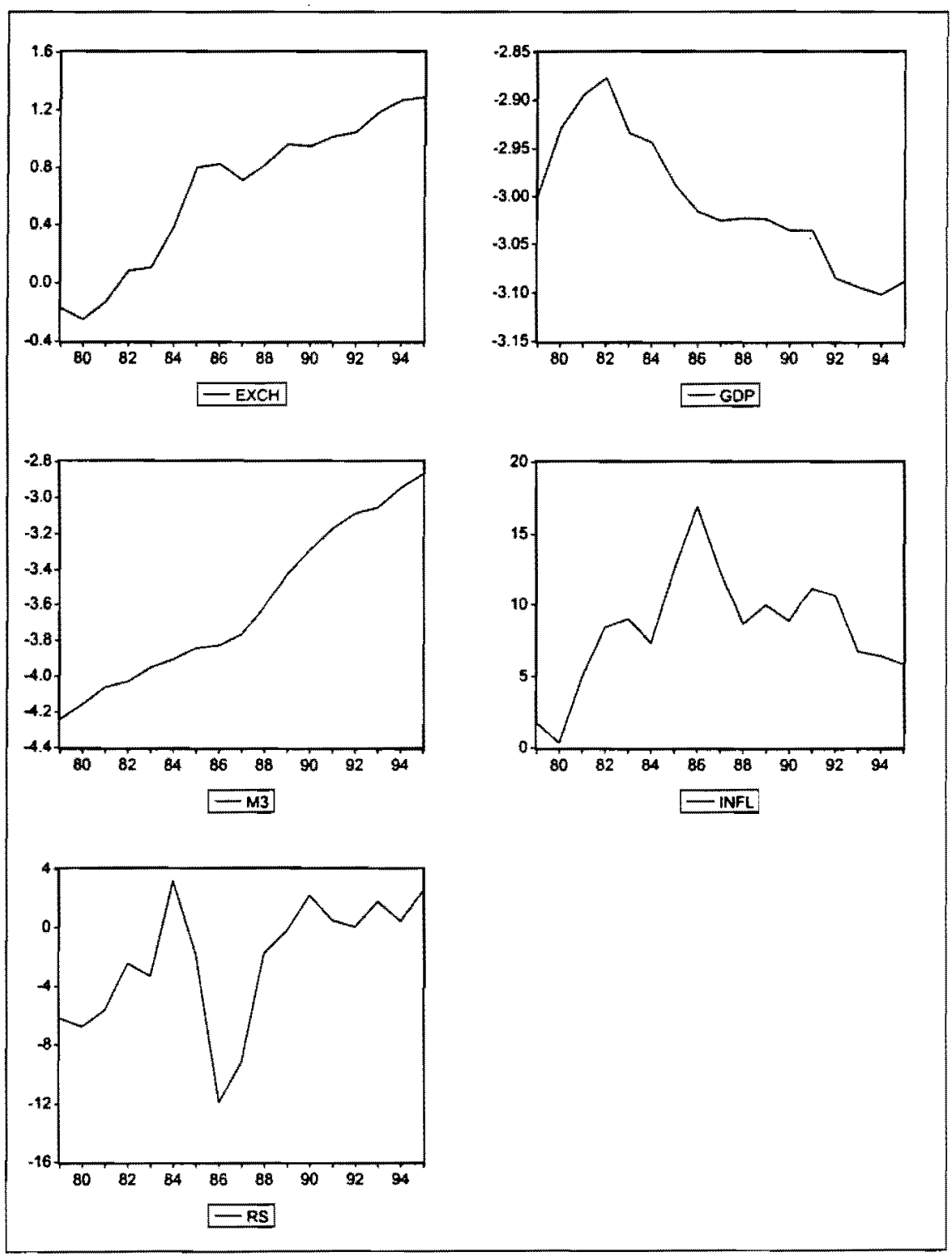


The results of the Augmented Dickey-Fuller tests for non-stationarity are reported in Tables 2 and 3. All variables appear to be integrated of order one, except for the variable RS which is stationary.

Table 2 Augmented Dickey-Fuller tests for non-stationarity, levels; 1979 - 1995

\begin{tabular}{|l|l|c|c|c|}
\hline Series & Model & Lags & $\mathrm{T}_{\mathrm{T}}, \mathrm{T}_{\mu}, \mathrm{T} \mathrm{0}$ & $\boldsymbol{\Phi}_{3}, \mathbf{\Phi}, \mathbf{0}$ \\
\hline EXCH & Trend and intercept & 0 & $-1,49$ & 1,29 \\
& Intercept & 2 & $-1,88$ & 2,66 \\
& None & 3 & 0,03 & \\
\hline \multirow{2}{*}{ GDP } & Trend and intercept & 1 & $-3,06$ & 4,17 \\
& Intercept & 0 & $-0,44$ & 0,19 \\
& None & 3 & 2,65 & \\
\hline \multirow{2}{*}{ M3 } & Trend and intercept & 1 & $-2,25$ & 3,18 \\
& Intercept & 0 & 0,66 & 0,44 \\
& None & 1 & $-1,84$ & \\
\hline \multirow{2}{*}{ NFL } & Trend and intercept & 0 & $-1,56$ & 2,32 \\
& Intercept & 0 & $-2,06$ & 4,27 \\
& None & 0 & $-0,49$ & \\
\hline \multirow{2}{*}{ RS } & Trend and intercept & 1 & $-3,32$ & 3,68 \\
& Intercept & 0 & $-1,98$ & 3,93 \\
& None & 0 & $-2,03 *$ & \\
\hline
\end{tabular}

*(**) Significant at a $5(1) \%$ level.

Table 3 Augmented Dickey-Fuller tests for non-stationarity, first differenced; 1979 - 1995

\begin{tabular}{|l|l|c|c|c|}
\hline Series & Model & Lags & $\mathrm{T}_{\mathrm{T}}, \mathrm{T}_{\mu}, \mathrm{T} 0$ & $\Phi_{3}, \Phi_{1}, 0$ \\
\hline EXCH & $\begin{array}{l}\text { Trend and intercept } \\
\text { Intercept } \\
\text { None }\end{array}$ & 1 & $-4,22^{*}$ & $6,18^{*}$ \\
\hline GDP & $\begin{array}{l}\text { Trend and intercept } \\
\text { Intercept } \\
\text { None }\end{array}$ & 0 & $-3,01$ & $6,13^{*}$ \\
& 2 & $-4,23^{* *}$ & \\
\hline
\end{tabular}


Table 3 continued

\begin{tabular}{|c|c|c|c|c|}
\hline Series & Model & Lags & $\mathrm{T}_{\mathrm{T}}, \mathrm{T}_{\mu}, \mathrm{T} \theta$ & $\Phi_{3}, \Phi_{1} 0$ \\
\hline M3 & $\begin{array}{l}\text { Trend and intercept } \\
\text { Intercept } \\
\text { None }\end{array}$ & $\begin{array}{l}0 \\
0\end{array}$ & $\begin{array}{l}-2,23 \\
-2,23\end{array}$ & $\begin{array}{c}2,49 \\
4,95^{*}\end{array}$ \\
\hline INFL & $\begin{array}{l}\text { Trend and intercept } \\
\text { Intercept } \\
\text { None }\end{array}$ & 1 & $-5,01^{* *}$ & $8,97^{* *}$ \\
\hline RS & $\begin{array}{l}\text { Trend and intercept } \\
\text { Intercept } \\
\text { None }\end{array}$ & $\begin{array}{l}0 \\
0\end{array}$ & $\begin{array}{l}-3,37 \\
-3,5^{*}\end{array}$ & $\begin{array}{c}5,67^{*} \\
12,27^{* *}\end{array}$ \\
\hline
\end{tabular}

*(**) Significant at a 5(1)\% level.

\subsection{The estimation results of the cointegration model}

The Engle and Yoo (1991) three-step estimation technique was employed, whose first step tests whether the set of variables specified in the cointegration equation is cointegrated, that is whether the particular combination of variables is in fact consistent with a long-run equilibrium relationship. The cointegration results for the first step are reported in Table 4.

Table 4 First step estimation results, dependant variable: $\mathbf{E X C H}_{\mathbf{t}}$

\begin{tabular}{|l|l|l|l|l|}
\hline Variable & Coefficient & Std. Error & t-Statistic & Probability \\
\hline $\mathrm{M}_{\mathrm{t}}$ & 0,842896 & 0,059393 & 14,19182 & 0,0000 \\
\hline $\mathrm{GDP}_{\mathrm{t}}$ & $-1,107141$ & 0,078135 & $-14,16952$ & 0,0000 \\
\hline $\mathrm{NFL}_{\mathrm{t}}$ & 0,041884 & 0,007885 & 5,312114 & 0,0001 \\
\hline R-squared & 0,951247 & F-statistic & 136,5808 \\
\hline Adjusted R-squared & 0,944282 & Prob(F-statistic) & 0,000000 \\
\hline
\end{tabular}

Figure 2 compares the actual values with the fitted values generated by the cointegration equation: 
Figure 2 The cointegration equation: actual, fitted and residual values

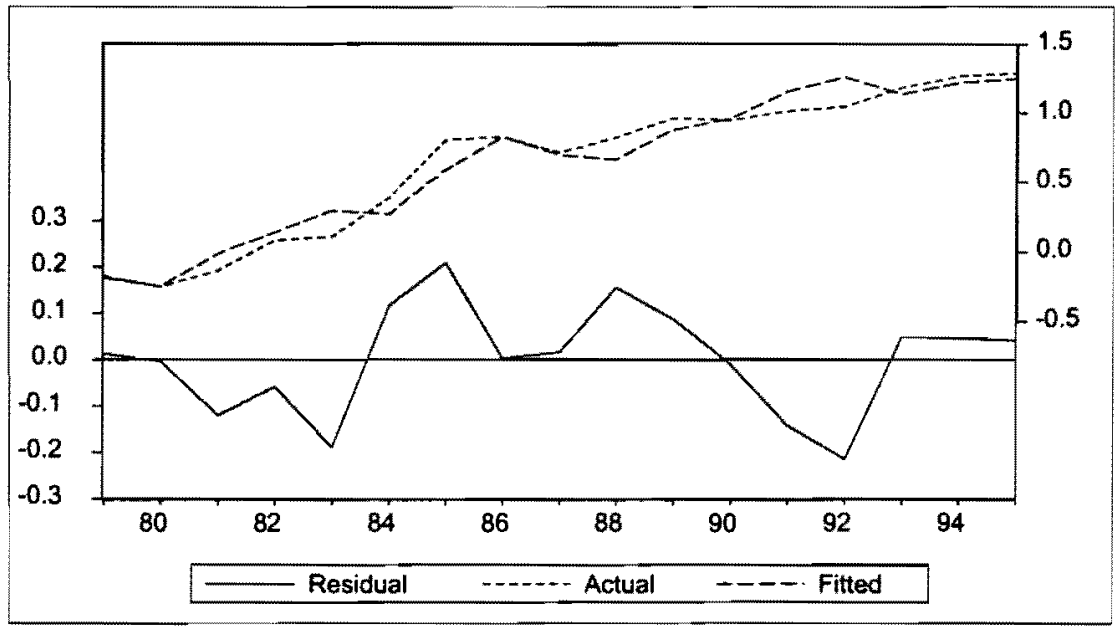

The cointegration regression augmented Dickey-Fuller test statistic was $-2,86$. This test consists of a unit root test on the residuals of the cointegration equation. Critical values for the relevant response surfaces can be found in MacKinnon (1991). The response surface for any number of regressors, excluding any constant and trend components, $1 \leq n \leq 6$, can be calculated as $C(p)=$ $\phi \infty+\phi_{1} T^{-1}+\phi_{2} T^{-2}$, where $C(p)$ is the $p$ per cent critical value. The residuals can thus be accepted as stationary, and the variables in the regression may be considered cointegrated.

\subsection{The error correction model}

The second stage of the Engle and Yoo procedure consists of an estimation of the short-run dynamics by means of an error correction model (ECM). It incorporates the equilibrium error (residual term) estimated from the long-run equilibrium relationship. In addition, the ECM provides an indication of the rate of adjustment towards equilibrium.

A summary of the estimation results is given in Table 5 . 
Table 5 Error correction estimation results, dependent variable: $\triangle \mathbf{E X C H}_{\mathbf{t}}$

\begin{tabular}{|c|c|c|c|c|c|}
\hline Variable & \multicolumn{2}{|c|}{ Coefficient } & Std Error & t-Statistic & Probability \\
\hline Residual $_{t-1}$ & \multicolumn{2}{|c|}{$-0,702699$} & 0,112142 & $-6,266169$ & 0,0008 \\
\hline$\Delta I N F L_{t}$ & \multicolumn{2}{|c|}{0,053977} & 0,007028 & 7,680255 & 0,0003 \\
\hline$\Delta \mathbf{R S}_{\mathbf{t}}$ & \multicolumn{2}{|c|}{0,029294} & 0,003987 & 7,347016 & 0,0003 \\
\hline$\Delta G P_{t-1}$ & \multicolumn{2}{|c|}{$-2,171331$} & 0,486008 & $-4,467682$ & 0,0042 \\
\hline$\Delta G D P_{1-2}$ & \multicolumn{2}{|c|}{$-2,297158$} & 0,431819 & $-5,319719$ & 0,0018 \\
\hline$\Delta \mathbf{R S}_{\mathrm{t}-1}$ & \multicolumn{2}{|c|}{0,012482} & 0,002872 & 4,345738 & 0,0048 \\
\hline$\Delta \mathbf{E X C H} \mathbf{H}_{t-1}$ & \multicolumn{2}{|c|}{0,382221} & 0,083693 & 4,566949 & 0,0038 \\
\hline DUM $_{t}$ & \multicolumn{2}{|c|}{$-0,054181$} & 0,020826 & $-2,601659$ & 0,0406 \\
\hline \multicolumn{2}{|l|}{ R-squared } & \multicolumn{2}{|c|}{0,968753} & F-statistic & 26,57362 \\
\hline \multicolumn{2}{|c|}{ Adjusted R-squared } & \multicolumn{2}{|c|}{0,932297} & Prob(F-statistic) & 00415 \\
\hline
\end{tabular}

In Table 5, DUM refers to a dummy variable of unity which was activated for three consecutive years: 1990, 1991 and 1992. An underestimation of the exchange rate for those three years prompted the inclusion of DUM. It appeared that factors which could not be captured in the model may have caused the exchange rate to perform better during those three years than could be explained by the variables at hand.

It is commonly accepted that the latter half of the eighties was a particularly dismal spell for the South African economy. Years of growing international discontent with South Africa's political dispensation, culminated in the debt standstill arrangement after President Botha's infamous Rubicon speech in 1985. South Africa's external relations were distorted by trade and financial sanctions, and extreme measures were taken to protect our international reserves and the exchange rate.

Political liberalization commenced in 1990 and brought substantial relief from international economic pressure. The international community endorsed the steps towards an equitable political dispensation by means of a rapid normalization of relations with South Africa. The exchange rate responded positively to international sentiments of optimism, the effect of which was prevalent particularly during 1990, 1991 and 1992 . The euphoria then seemed to subside 
and normality returned.

A data plot of the actual and the fitted values of $\triangle \mathrm{EXCH}$ is shown in Figure 3.

Figure 3 The actual, fitted and residual values of $\triangle \mathrm{EXCH}$

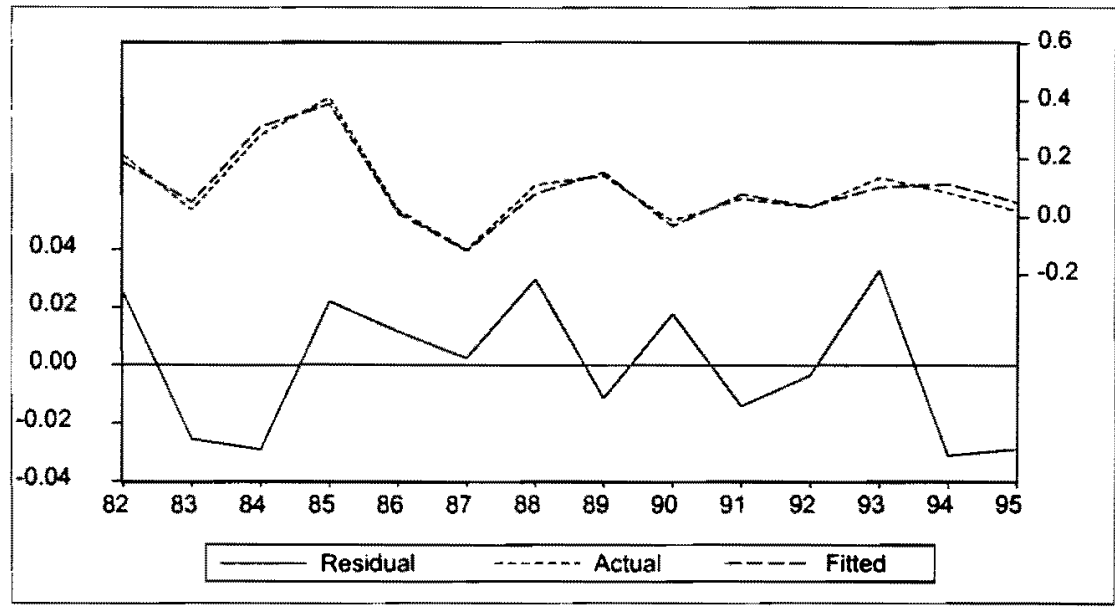

Several diagnostic tests were performed on the ECM. The results of these tests are reported in Table 6 . It should be borne in mind, however, that the conclusiveness of these tests is reduced by the relatively small size of the sample.

Table 6 Diagnostic test results

\begin{tabular}{|l|l|l|l|}
\hline Purpose of test & Test & Test Statistic $^{1}$ & Probability $^{-1}$ \\
\hline Normality & Jarque-Bera & $\mathrm{JB}(2)=1,499815$ & 0,472410 \\
\hline Heteroscedasticity & ARCH & $\mathrm{nR}^{2}(1)=0,517441$ & 0,471935 \\
\hline Serial correlation & Breusch-Godfrey LM & $\mathrm{nR}^{2}(2)=13,09462$ & 0,001434 \\
\hline Stationarity of residuals & Lung Box Q & $\mathrm{Q}(6)=3,7457$ & 0,711 \\
\hline Specification & Ramsey RESET & $\mathrm{LR}(2)=0,836750$ & 0,658115 \\
\hline Parameter stability & $\begin{array}{l}\text { CUSUM, CUSUM of } \\
\text { Squares, Recursive } \\
\text { Estimates, Recursive } \\
\text { Residuals }\end{array}$ & All indicative of stability \\
\hline
\end{tabular}


The White test for heteroscedasticity could not be performed because the sample contains fewer than the minimum number of observations required.

The third step in the Engle and Yoo procedure was subsequently performed.

\subsection{Cointegration correction and adjusted coefficients}

The third step corrects the first-step estimation of the long-run parameters of the model to ensure that distributions return to a normal distribution. For this purpose, the coefficients and $t$-statistics are adjusted to their true values.

Tables 7 and 8 summarize the third-step estimation results and the adjusted coefficients.

Table 7 Third-step estimation results

\begin{tabular}{|c|c|}
\hline Variable & Adjustment of Coefficients \\
\hline $0,702699 * \mathrm{M}_{\mathrm{t}}$ & $-0,007906$ \\
\hline $0,702699 * \mathrm{GDP}_{\mathrm{t}}$ & 0,017437 \\
\hline $0,702699 * \mathrm{NFL}_{\mathrm{t}}$ & 0,002570 \\
\hline
\end{tabular}

Table 8 Cointegration correction, dependent variable: $\mathbf{E X C H}_{t}$

\begin{tabular}{|l|l|l|l|l|}
\hline Variable & $\begin{array}{l}\text { Engle and } \\
\text { Granger } \\
\text { Coefficients }\end{array}$ & $\begin{array}{l}\text { Engle and } \\
\text { Yoo Adjusted } \\
\text { Coefficients }\end{array}$ & $\begin{array}{l}\text { Standard } \\
\text { Error }\end{array}$ & $\begin{array}{l}\text { Adjusted } \\
\text { t-statistic }\end{array}$ \\
\hline $\mathrm{M}_{\mathrm{t}}$ & 0,842896 & 0,834990 & 0,022389 & 37,294653 \\
\hline $\mathrm{GDP}_{\mathrm{t}}$ & $-1,107141$ & $-1,089704$ & 0,023212 & $-46,945717$ \\
\hline $\mathrm{INFL}_{\mathrm{t}}$ & 0,041884 & 0,044454 & 0,003570 & 12,4521 \\
\hline
\end{tabular}

The three-step Engle and Yoo procedure is thus concluded and the final version of the model is obtained by combining the long- and short-run characteristics. The overall fit of the model is depicted in Figure 4. 


\section{Figure 4 The actual and fitted values of EXCH}

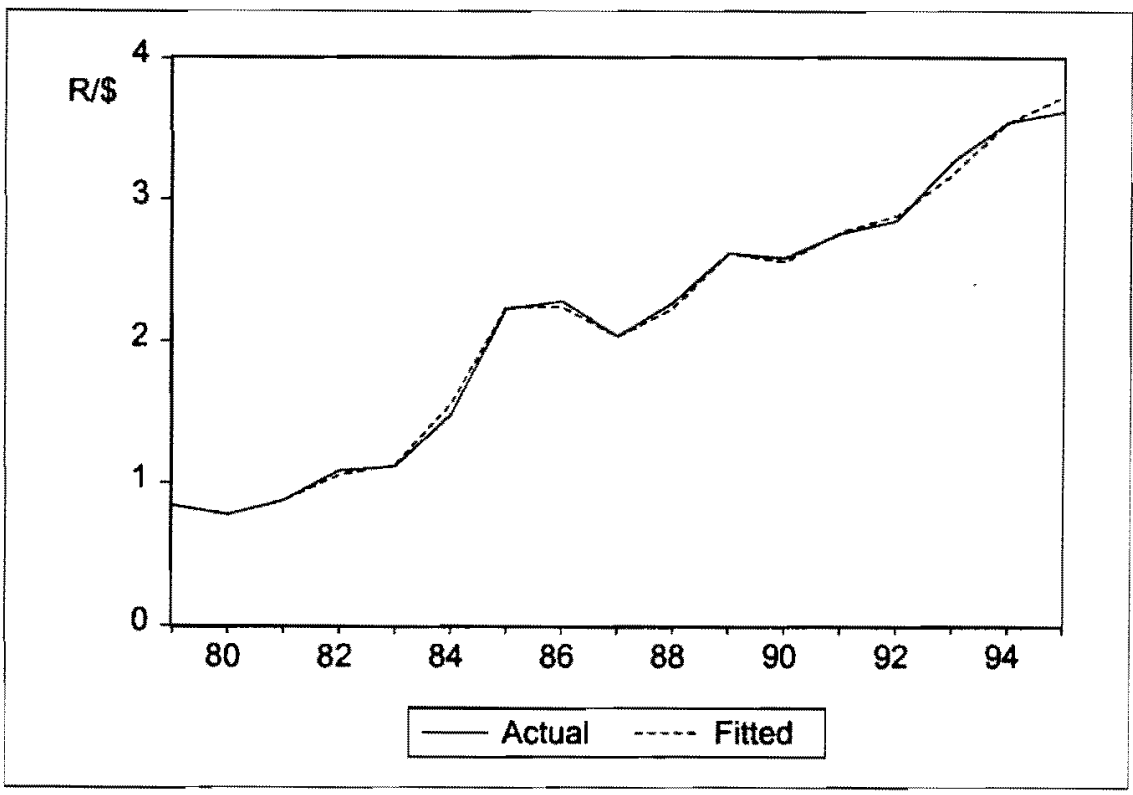

\section{DYNAMIC RESPONSE PROPERTIES AND POLICY IMPLICATIONS}

The rand/dollar model was subsequently subjected to sensitivity testing. Sensitivity testing in the form of dynamic simulations will determine whether the resulting multiplier effects are consistent and therefore whether the model is stable and robust. In addition, the dynamic response properties reveal some of the policy implications of the model. The response characteristics and some policy implications are discussed in this section.

\subsection{Sensitivity tests}

The variables were shocked, one at a time, as follows: Firstly, a shock was applied to GDP, allowing the South African GDP to rise 10 per cent above its baseline level from 1982 onwards. Ideally, the shock should result in a convergence of the dependant variable, $\mathrm{EXCH}$, on 10 per cent of the estimated coefficient of the shocked variable, GDP. The second shock consisted of an increase of 3 percentage points in the domestic inflation rate from 1982 onwards, and EXCH should converge on the estimated coefficient of INFL multiplied by 3 . 
The final shock was a 10 per cent increase in the South African M3 money supply, also from 1982 onwards. Similarly, EXCH should converge on 10 per cent of the estimated coefficient of the M3 variable.

On practical grounds, 1982 was considered appropriate to commence with each of the three shocks respectively. The shocks could not be applied later, because the sample period is short and sufficient time for the multiplier effect to develop had to be allowed. Nor could it be applied sooner, to allow for two-period time lags.

Table 9 indicates the divergence in the long-run equilibrium value of the exchange rate by the end of the sample period, 1995.

Table 9 Difference between the baseline forecast and forecasts with shocked variables, dependent variable: EXCH

\begin{tabular}{|l|l|l|l|}
\hline Variable & Coefficient & $\begin{array}{l}\text { Expected change } \\
\text { in EXCH }\end{array}$ & $\begin{array}{l}\text { Divergence in } \\
\text { EXCH in 1995 }\end{array}$ \\
\hline M3 & 0,834990 & 0,083499 & 0,083603 \\
\hline GDP & $-1,089704$ & $-0,108970$ & $-0,106392$ \\
\hline INFL & 0,044454 & 0,133362 & 0,134085 \\
\hline
\end{tabular}

The results of the sensitivity tests in Table 9 are shown in Figures 5, 6 and 7.

2 The expected change in EXCH will be 10 per cent of the relevant coefficients in the case of the M3 and GDP shocks, and in the case of the INFL shock, the coefficient of INFL multiplied by 3 should provide an indication of the expected adjustment in the long-run equilionium value of $\mathrm{EXCH}$. 
Figure 5 Dynamic adjustment properties (in percentage of change) with a 10 per cent increase in the South African M3 money supply, dependent variable: $\mathrm{EXCH}$

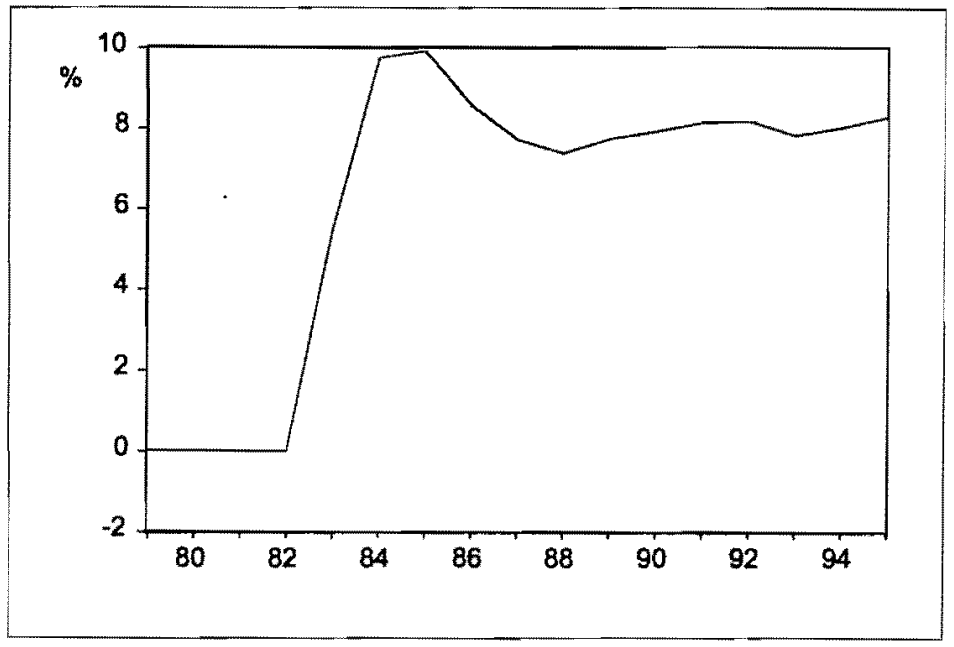

Figure 5 shows that a domestic monetary shock in 1982 results in a sharp depreciation in the rand (an increase in EXCH), amounting to a maximum of just below 10 per cent in 1985, followed by a relatively smooth adjustment path towards a new long-run equilibrium which, by the end of the sample period in 1995 , stabilizes around R4,08/dollar compared to the baseline forecast of R3,77. This constitutes a depreciation of 8,36 per cent in the dollar value of the rand.

The mild initial response of the exchange rate to the money supply shock is consistent with what may be expected. It should be borne in mind that the upper boundary of the annual money supply growth has been around 10 per cent for some years. This target was exceeded by far, particularly during the eighties when monetary growth at times doubled the target rate. The 10 per cent shock introduced in 1982 therefore constitutes a relatively small shock, which would explain why the initial exchange rate response is a moderate one of less than 10 per cent. Naturally, monetary expansion is likely to be inflationary and, moreover, it creates inflationary expectations. The exchange rate could be expected to depreciate in such a climate. The new long-run equilibrium is at a plausible level, depreciating 8,36 per cent from the baseline forecast, given the magnitude of the shock applied to the money supply. 
Figure 6 Dynamic adjustment properties (in percentage of change) with a 10 per cent increase in the South African GDP, dependent variable: EXCH

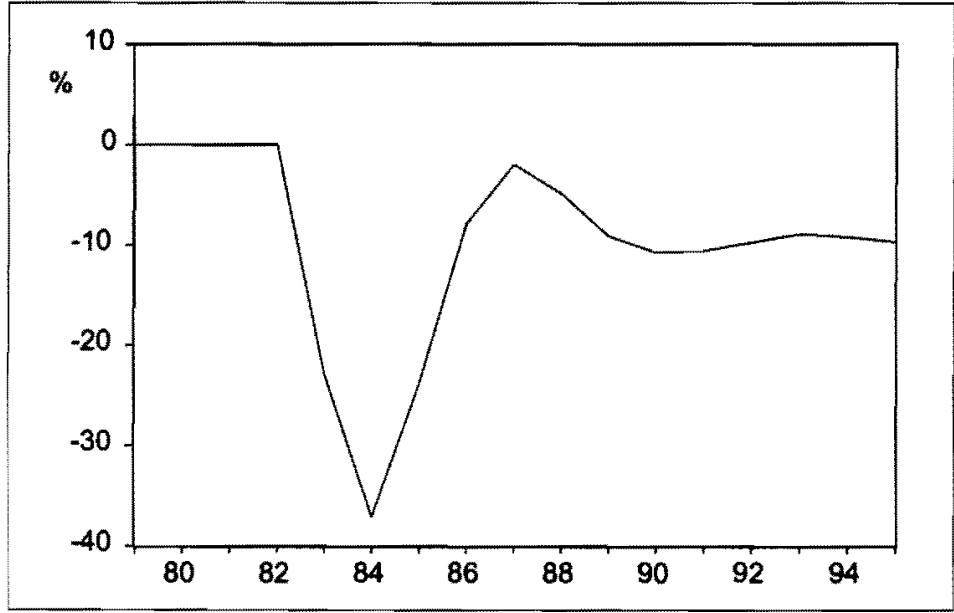

Figure 6 shows that a 10 per cent rise in the SA GDP relative to the US GDP has a pronounced impact on the exchange rate. Having been dealt the GDP shock in 1982, the exchange rate appreciates dramatically (EXCH declines) to a turning point of a just below 40 per cent appreciation in 1984, and almost retums to its pre-shock level in 1987. Although the magnitude of the initial response is somewhat unexpected, it must be borne in mind that a 10 per cent shock is, in terms of national outputs, sizeable. South Africa's annual GDP growth for the 1982 to 1995 period was, on average, slightly above 1 per cent. A 10 per cent shock to the South African GDP therefore represents a substantial shock. Given the openness of the economy, an expansion in the GDP is commonly preceded by an increase in exports, which in tum supports the exchange rate. A close to 40 per cent initial appreciation in the exchange rate is therefore not implausible, considering the order of magnitude of the GDP shock.

The exchange rate then adjusts relatively smoothly to a new long-run equilibrium level of $\mathrm{R} 3,39$, compared to the baseline forecast of $\mathrm{R3}, 77$, signalling an appreciation of 10,64 per cent. The new long-run equilibrium is consistent with the model coefficients and intuitively plausible. 
Figure 7 Dynamic adjustment properties (in percentage of change) with a three percentage point increase in the South African inflation rate, dependent variable: $\mathbf{E X C H}$

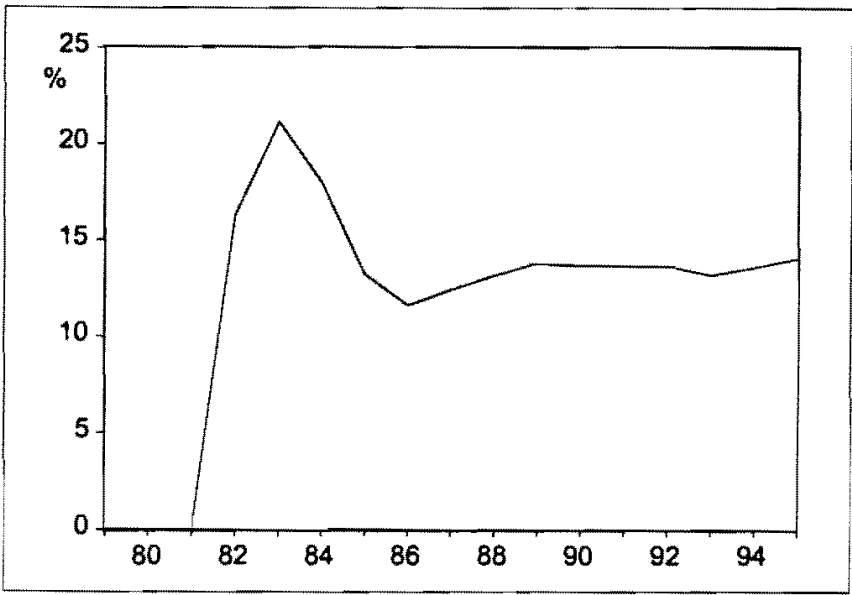

The average annual inflation rate for the period 1982 to 1995 exceeded 13 per cent. A 3 percentage points shock to the South African inflation rate is therefore sufficient to trigger a significant exchange rate response. A year after the shock is applied, the exchange rate depreciation reaches its maximum where after the new inflation differential is discounted. The initial depreciation exceeding 20 per cent is reversed in 1983 and a partial recovery is followed by a smooth adjustment path towards a long-run equilibrium value. In 1995, the exchange rate with the inflation shock settles at $R 4,27$, compared to the baseline forecast of $R 3,77$, constituting a depreciation of 13,41 per cent.

\subsection{Policy implications}

Some simple policy recommendations may be construed from the sensitivity tests performed in the previous section. It would seem that monetary stability is important, but much more so, particularly in the short run, are economic growth and price stability.

Domestic economic growth has a pronounced short-run effect on the exchange rate: An appreciation of almost 40 per cent within two years for every ten per cent GDP growth, ceteris paribus. The long-run effect is also significant as indicated by the relatively high GDP elasticity of $-1,09$. Domestic policies aimed at the expansion of economic activity are not primarily intended to support the exchange rate. The unprecedented level of unemployment is undoubtedly the 
most pressing policy priority in South Africa. However, the current growth and employment strategy (commonly referred to as the Growth, Employment and Redistribution Strategy, or GEAR) relies heavily on the potential contribution of a competitive export sector and, in this regard, the level of the exchange rate is clearly a deciding factor.

Economic growth supports the exchange rate and, although it eases the pressure on the balance of payments when it serves to attract foreign capital, export competitiveness may be eroded. It should be bome in mind that several other structural considerations, the importance of which outweighs the threat posed by an exchange rate appreciation, constrain our export performance. The amelioration of the structural constraints will in all probability further reduce the importance of an exchange rate effect on our export competitiveness.

In short, economic growth is a sine qua non in the quest for adequate labour absorption; if policymakers envisage to attain that via a vigorous export performance, the exchange rate effect of growth may prove detrimental to export competitiveness, and should be offset by removing structural constraints on competitiveness.

Monetary stability is a prerequisite for both the internal and external stability of the rand. It has a significantly smaller short-run effect on the exchange rate; a 10 per cent expansion in the domestic money supply results in a less than 10 per response in the exchange rate. Similarly, the long-run exchange rate effect is smaller than in the case of economic growth, as is evident from the lower elasticity of 0,83 . Monetary stability is consistent with the GEAR objectives of sustained, export-led, long-term growth. Moreover, monetary discipline was probably never more important for an emerging economy to dispell fears of a looming financial collapse in the wake of the Asian crisis of 1997. Price stability is equally important for exchange rate stability, as is evident from the sensitivity tests in the previous section. It is therefore, apart from the other GEAR objectives, also important from the perspective of exchange rate stability, to check the expansion of the money supply and the rate of increase in consumer prices. Put differently, monetary and fiscal discipline needs to be adhered to with perseverance.

In summary, the GEAR objectives are an increase in the labour absorption capacity and a more equitable distribution of income through sustained, exportled, long-term growth. For this, demand-management policies need to be disciplined and consistent, and supply-side measures should be directed at appropriate structural adjustments to enhance export competitiveness and establish an attractive investment haven. Exchange rate stability, which is a crucial element of the strategy, will not be derailed by such policy measures, with 
the possible exception of an appreciation in the currency should the vigor of the economy be revived. The resulting threat to export competitiveness would be countered if significant structural impediments are effectively dismantled.

\section{THE FUNDAMENTAL EQUILIBRIUM EXCHANGE RATE (FEER)}

The concept of an equilibrium exchange rate has frequently been misinterpreted as a normative or even subjective concept (Barrell et al., 1996: 5). The real equilibrium exchange rate is an objective rate inasmuch as it is consistent with equilibrium of the underlying fundamentals. It should be conceded though, that in the quest for a purer construct of FEERs (or in IMF terminology, the desired equilibrium exchange rate, DEER), the definitions encountered may vary considerably and that the FEER concept may be subjective in the sense that it corresponds to a subjective set of assumptions.

It remains undisputed that an equilibrium exchange rate is one which is consistent with prevailing relative prices and some definition of intemal and external equilibrium. Purchasing power parity may be used to determine FEERs (Barrell et al., 1996: 6). Altematively, the FEER may be considered the real effective exchange rate where both internal and external macroeconomic equilibrium are achieved, and to then solve for the real exchange rate consistent with the particular definitions of internal and external equilibrium (Bayoumi et al., 1993: 1). Internal equilibrium is usually defined to occur at potential or fullemployment output and is determined independently of the real exchange rate. External equilibrium is often defined in terms of a desired balance on the current account, which should correspond to a presumed level of capital flow and stock of net foreign assets (op. cit.: 3 ).

A version of the latter approach will be applied to the exchange rate model described in section 5 above, and a unique definition for equilibrium is subsequently formulated.

\subsection{Defining fundamental equilibrium}

Several South African policymakers have repeatedly confirmed their commitment to the government's comprehensive macroeconomic (GEAR) strategy. The GEAR is fairly specific, albeit somewhat ambitious, about the target (or desired) levels of macroeconomic fundamentals until the year 2000 . Consequently, fundamental equilibrium, or simultaneous internal and extemal equilibrium, is defined as the level of macroeconomic fundamentals consistent with GEAR targets. Naturally, some assumptions have to be made about the 
corresponding US fundamentals. All that remains then, is to solve for the exchange rate consistent with the GEAR targets and to call it the fundamental equilibrium exchange rate.

\subsection{Target (desired) levels of the fundamentals}

The GEAR projections of the relevant fundamentals are given in Table 10 .

Table 10 Projections for economic growth, the inflation rate, monetary growth and interest rates:

\begin{tabular}{|l|l|l|l|l|l|}
\hline Variable & 1996 & 1997 & 1998 & 1999 & 2000 \\
\hline Growth & $3,3 \%$ & $2,0 \%$ & $2,5 \%$ & $2,9 \%$ & $3,3 \%$ \\
\hline Inflation & $8,4 \%$ & $10,9 \%$ & $9,6 \%$ & $9,3 \%$ & $9,1 \%$ \\
\hline Monetary growth & $11,7 \%$ & $12,9 \%$ & $12,1 \%$ & $12,2 \%$ & $12,4 \%$ \\
\hline $\begin{array}{l}\text { Real short-term } \\
\text { interest rates }\end{array}$ & $6,45 \%$ & $2,95 \%$ & $3,25 \%$ & $3,05 \%$ & $2,45 \%$ \\
\hline
\end{tabular}

Monetary growth was calculated as the sum of economic growth and the inflation rate for each year. Monetary growth is not specified in the GEAR beyond the explicit commitment to monetary discipline. The Reserve Bank's target for annual growth in the M3 money supply has for many years had 10 per cent as its upper boundary. In reality, monetary growth has been well outside of the growth targets for a number of years. Despite the weakening link between the inflation and economic growth rates on the one hand and the rate of monetary expansion on the other, it was decided to predict a monetary growth rate consistent with the GEAR targets for inflation and economic growth. The reason for this was simply that the Reserve Bank's targets appeared to have severed the links with reality and were not well ensconced in the context of the GEAR targets.

Similarly, the real short-term interest rate is not expressly forecasted in the GEAR. Future movements in the bank rate are specified, however, and similar movements were then imposed on the 3-month BA rate to obtain a forecast of the nominal short-term interest rate. GEAR inflation rates were then used to predict the trajectory of the real short-term interest rate.

Assumptions had to be made regarding the corresponding US fundamentals. It was assumed that economic growth in the USA continues steadily at 3 per cent per annum. The inflation rate was assumed to remain at 3 per cent and 8 per cent was considered a reasonable annual rate of monetary expansion. The real short- 
term interest rate was obtained by subtracting the assumed 3 per cent inflation from the Project Link forecasts for the nominal 3-month Treasury Bill rate.

\subsection{The FEER for the rand}

The model specified in section 5 was then estimated again, taking the forecasted data for 1996 to 2000 into account. Figure 7 shows the development in the dependent variable, EXCH, with actual data until 1995 and then with predicted data until 2000.

Figure 8 Actual and fitted values (1979 to 1995) and the fundamental equilibrium exchange rate (1996 to 2000); dependent variable: EXCH

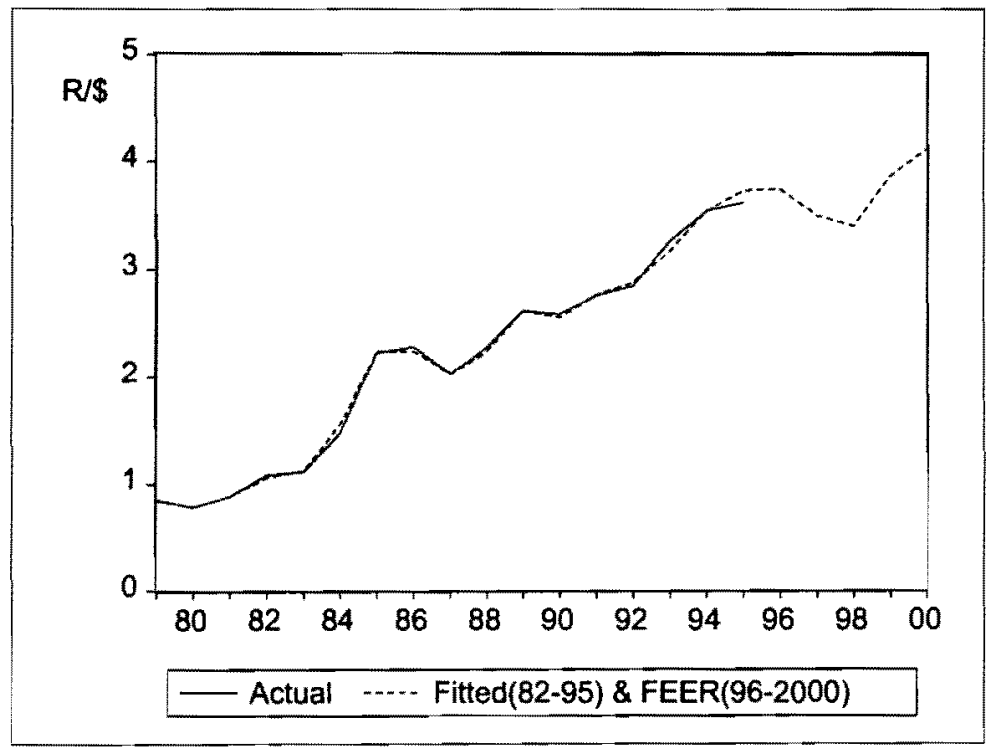

The trajectory coincides with the earlier version of the model until 1995, after which EXCH develops along a path consistent with GEAR targets. The fitted values for 1996 to 2000 therefore constitute the fundamental equilibrium exchange rate, or FEER. Table 11 reports the FEER values generated for 1996 to 2000 . 
Table 11 The fundamental equilibrium exchange rate (rand/dollar) for 1996 to 2000

\begin{tabular}{|c|c|}
\hline Year & Value of FEER \\
\hline 1996 & 3747166 \\
\hline 1997 & 3505590 \\
\hline 1998 & 3410756 \\
\hline 1999 & 3867370 \\
\hline 2000 & 4124758 \\
\hline
\end{tabular}

Of the FEER values reported in Table 11, the values for 1996, 1997 and 1998 may be compared with the actual exchange rates observed. These actual rates were R4,2964/dollar, R4,6073/dollar and R5,5316 respectively, compared to the corresponding FEER values of R3,7472/dollar, R3,5056/dollar and $\mathrm{R} 3,4108 /$ dollar. Clearly, the rand is performing sub-optimally, or may be considered undervalued compared to the equilibrium rate. Given that the FEER values are consistent with the GEAR target levels of fundamental variables, any deviation of these underlying fundamentals will result in a deviation of the exchange rate from its FEER value. The factors which contributed to the undervaluation of the exchange rate were, firstly the sub-optimal performance of the economy in terms of the level of economic activity. The growth rates of 1996,1997 and 1998 were significantly lower than the rates envisaged in the GEAR. In addition, the M3 money supply expanded at a rate much higher than projected. The actual inflation rates compare more favourably with the GEAR projections, but not sufficiently so to avoid an undervaluation of the exchange rate. The undervaluation has the advantage that it supports South Africa's export competitiveness, but the balance of payments and level of reserves are almost constantly under pressure.

For the future exchange rate to converge on the equilibrium rate, a robust economic recovery will have to materialize and the expansion of M3 will have to be kept in check.

\section{CONCLUSION}

This study set out to establish an appropriate theoretical approach to modelling the rand/dollar exchange rate, given that none of the possible approaches escapes 
all imperfection. The monetary approach was selected despite its shortcomings and poor empirical record, mainly because a clear altemative is lacking.

An equation for the estimation of the rand/dollar exchange rate was then specified, and the Engle and Yoo three-step procedure applied to estimate the model. The results indicated that the exchange rate, GDP, M3 money supply and inflation variables, specified in Table 1, are cointegrated. The real short-run interest differential and a dummy variable for the years 1990, 1991 and 1992 were added to explain the short-run dynamics of the model and, finally, the third step was applied to adjust the long-run coefficients to their true values.

The dynamic adjustment properties were investigated by applying exogenous shocks to each of the long-run variables separately. In each case, the adjustment path after the initial shock was smooth and the deviation of the new long-run exchange rate from the baseline converged to the expected value as indicated by the magnitude of the relevant coefficient.

Subsequently, sensitivity tests were interpreted to derive some policy implications, given the firm commitment of policymakers in South Africa to adhere to the proposals of the GEAR strategy. It was found that, should the labour absorption and economic expansion envisaged in the GEAR materialize, an overvalued exchange rate may well be the result which, in tum, poses a threat for sustained export-led growth. However, should the policy making authorities manage to honour their commitment to price stability and monetary discipline, the resulting exchange rate stability will be conducive to an export-driven road to economic recovery.

Finally, an attempt was made to reconcile the exchange rate model with the ideal or target values for the underlying fundamentals specified in the GEAR. The result is considered a fundamental equilibrium exchange rate, or FEER, where the latter is defined as the rand/dollar exchange rate consistent with the GEAR targets. For 1996, 1997 and 1998 actual observations of the FEER variables were compared with their estimated values, and it was concluded that the actual exchange rate appears to have been undervalued in both periods, given that some of the fundamentals clearly fall short of the GEAR targets. The definition of the FEER as the exchange rate consistent with the GEAR targets is however purely arbitrary, and altemative definitions may certainly be useful, particularly if the GEAR should lose further credibility. However, the FEER projections defined here do seem credible, if the effect of the Asian crisis on the rand/dollar rate is separated from the exchange rate level dictated by fundamentals. Had South Africa been spared the misfortunes of the other emerging markets of the past three years, the actual exchange rate would have deviated from the FEER only to the extent that GEAR targets were not met. This inevitably raises questions about 
the usefulness of structural models such as the monetary rand/dollar model: its forecasting reliability collapses during crises when it is most needed. Realistically, it should be added that the purpose of a structural model is hardly to forecast a crisis. Much rather, in this instance at least, it serves as an indication of whether the current exchange rate is overvalued or undervalued and also how adjustments in the fundamentals may be expected to affect the rand.

8 REFERENCES

1 ARGY, V. (1989) "Financial Integration, Short Run Exchange Rate Volatility in Portfolio Balance Models", Australian Economic Papers, 28(52): 29-38.

2 ARTIS, M.J. and TAYLOR, M.P. (1993) "Deer Hunting: Misalignment, Debt Accumulation and Desired Equilibrium Exchange Rates", IMF Working Paper, no. 48: 1-23.

3 BARRELL, R.; ANDERTON, B.; LANSBURY, M. and SEFTON, J. (1996) FEERs for the NIEs. Exchange Rate Policies and Development Strategies in Taiwan, Korea, Singapore and Thailand, National Institute of Economic and Social Research: 1-42.

4 BAYOUMI, T.; CLARK, P.; SYMANSKY, S. and TAYLOR, M.P. (1994) "Robustness of Equilibrium Exchange Rate Calculations for Alternative Assumptions and Methodologies", IMF Working Paper, no. 17: $1-42$.

5 BILSON, J.F.O. (1978) "The Monetary Approach to the Exchange Rate: Some Empirical Evidence", IMF Staff Papers, 25(1): 48-75.

6 BILSON, J.F.O. (1979) "Recent Developments in Monetary Models of Exchange Rate Determination", IMF Staff Papers, 26(2): $201-23$.

7 BILSON, J.F.O. (1984) "Exchange Rate Dynamics", in Exchange Rate Theory and Practice, Bilson J.F.O. and Marston, R.C. (eds.), The University of Chicago Press, Chicago: 175-98.

8 BILSON, J.F.O. and MARSTON, R.C. (1984) Exchange Rate Theory and Practice, The University of Chicago Press, Chicago.

9 BOUGHTON, J.M. (1988) "The Monetary Approach to Exchange Rates: What Now Remains?", Essays in International Finance, no. 171, Princeton University, New Jersey.

10 DOOLEY, M.P. and ISARD, P. (1982) "A Portfolio Balance Rational Expectations Model of the Dollar-Mark Exchange Rate", Journal of International Economics, 12: 257-76.

11 DORNBUSCH, R. (1976) "Expectations and Exchange Rate Dynamics", Journal of Political Economy, 84(6): 1161-76. 
12 DORNBUSCH, R. (1976) "The Theory of Flexible Exchange Rate Regimes and Macroeconomic Policy", Scandinavian Journal of Economics, 78(3): 255-79.

13 DORNBUSCH, R. (1980) "Exchange Rate Economics: Where do we Stand?" Brookings Papers on Economic Activity, no. I, The Brookings Institution, Washington DC.

14 DORNBUSCH, R. (1983) "Exchange Rate Economics: Where Do We Stand?", in Economic Interdependence and Flexible Exchange Rates, Bhandari, J.S. and Putnam, B.H. (eds.), Massachusetts Institute of Technology, Press, USA: 45-83.

15 DORNBUSCH, R. (1987) "Exchange Rate Economics: 1986", The Economic Joumal, 97: 1-18.

16 DORNBUSCH, R. (1990) "Exchange Rate Economics, in Current Issues in International Monetary Economics", Llewellyn, D. and Milner, C. (eds.), MacMillan Education Ltd, London: 13-43.

17 DRISKILL, R.A. (1981) "Exchange Rate Dynamics. An Empirical Investigation", Journal of Political Economy, 89: 357-71.

18 DRISKILL, R.A.; MARK, N.C. and SHEFFRIN, M.S. (1992) "Some Evidence in Favor of a Monetary Rational Expectations Exchange Rate Model with Imperfect Capital Substitutability", International Economic Review, 33(1): 223-37.

19 FRANKEL, J.A. (1979) "On the Mark: A Theory of Floating Exchange Rates Based on the Real Interest Differentials", The American Economic Review, 69(4): 610-22.

20 FRANKEL, J.A. (1980) Monetary and Portfolio Models of Exchange Rate Determination, Paper presented at the World Congress of the Econometric Society, Aix-en-Provence, France, August 29, 1980.

21 FRANKEL, J.A. (1983) "Monetary and Portfolio-Balance Models of Exchange Rate Determination", in Economic Interdependence and Flexible Exchange Rates, Bhandari, J.S. and Putnam, B.H. (eds.), Massachusetts Institute of Technology, Press, U.S.A.: 84-115.

22 FRANKEL, J.A. (1984) "Tests of Monetary and Portfolio Balance Models of Exchange Rate Determination", in Exchange Rate Theory and Practice, Bilson J.F.O. and Marston, R.C. (eds.), The University of Chicago Press, Chicago: 239-60.

23 FRANKEL, J.A. and ROSE, A.K. (1994) "A Survey on Empirical Research on Nominal Exchange Rates", NBER Working Paper, no, 4865: $1-72$.

24 FRENKEL, J.A. (1976) "A Monetary Approach to the Exchange Rate: Doctrinal Aspects and Empirical Evidence", Scandinavian Journal of Economics, 1976: 200.

25 FRENKEL, M. (1995) "Leaming and Exchange Rate Dynamics", Journal of Studies in Economics and Econometrics, 19(3): 1-17. 
26 GROS, D. (1989) "On the Volatility of Exchange Rates - Tests of Monetary and Portfolio Balance Models of Exchange Rate Determination", Weltwirtschafliches Archiv, 125(2): 3-95.

27 HACCHE, G. and TOWNEND, J.C. (1981) "Monetary Models of Exchange Rates and Exchange Market Pressure: Some General Limitations and an Application to Sterling's Effective Rate", Weltwirtschafliches Archiv, 117(4): 622-37.

28 HALL, S. and GARRATT, A. (1992) "Model Consistent Learning and Regime Switching", Centre for Economic Forecasting (London Business School) Discussion Paper, January, 2; 33.

29 HOOPER, P. and MORTON, J. (1982) "Fluctuations in the Dollar: A Model of Nominal and Real Exchange Rate Determination", Journal of International Money and Finance, 1(1): 39-56.

30 ISARD, P. (1987) "Lessons from Empirical Models of Exchange Rates", IMF Staff Papers, 34(1): 1-28.

31 ISARD, P. (1995) Exchange Rate Economics, Cambridge University Press, USA: $1-275$.

32 MACDONALD, R. (1985) "Are Deviations from Purchasing Power Parity Efficient? Some Further Answers", Weltwirtschafliches Archiv, 121: 638-45.

33 MACDONALD, R. and TORRANCE, T.S. (1988) "Exchange Rates and the "News": Some Evidence Using UK Survey Data", Manchester School of Economics and Social Studies, 56(1): 69-76.

34 MACDONALD, R. (1988) Floating Exchange Rates: Theories and Evidence, Unwin Hyman, London.

35 MACDONALD, R. and TAYLOR, M.P. (1989) Exchange Rates and Open Economy Macroeconomics, Basil Blackwell, Oxford.

36 MACDONALD, R. (1990) "Empirical Studies of Exchange Rate Determination", in Current Issues in International Monetary Economics, Llewellyn, D. and Milner, C. (eds.), MacMillan Education Ltd, London: 63-100.

37 MACDONALD, R. (1991) "Long Run Purchasing Power Parity: Is it for Real?", Dundee Discussion Paper, May.

38 MACDONALD, R. and TAYLOR, M.P. (1992) Exchange Rate Economics, vols. I and II, Edward Elgar Publishing House Ltd., Aldershot.

39 MACDONALD, R. and TAYLOR, M.P. (1992) 'Exchange Rate Economics: A Survey", IMF Staff Papers, 39(1): 1-57.

40 MACDONALD, R. and TAYLOR, M.P. (1992) "The Monetary Approach to the Exchange Rate: Rational Expectations, Long-run Equilibrium and Forecasting" IMF Working Paper, 34, May.

41 MACDONALD, R. and TAYLOR, M.P. (1993) "The Monetary Approach to the Exchange Rate: Rational Expectations, Long-Run Equilibrium and Forecasting" IMF Staff Papers, 40(1): 89-107. 
42 MACDONALD, R. (1995) "Long-run Modeling: A Survey of the Recent Evidence", IMF Staff Papers, 42(3): 437-89.

43 MACKINNON, J. (1991) "Critical Values for Cointegration Tests", in Long-Run Economic Relationships, Engle, R.F. and Granger, C.W.J. (eds.), Oxford University Press.

44 MARSTON, R.C. (1997) "Tests of Three Parity Conditions: Distinguishing Risk Premia and Systematic Forecast Errors", Journal of International Money and Finance, 16(2): 285-303.

45 OBSTFELD, M. and ROGOFF, K. (1995) Exchange Rate Dynamics Redux. Joumal of Political Economy, 103(3): 624-60.

46 TAYLOR, M.P. (1995) "Exchange Rate Modelling and Macro Fundamentals: Failed Partnership or Open Marriage?" British Review of Economic Issues, 17(42): 1-42.

47 TAYLOR, M.P. (1995) The Economics of Exchange Rates. Journal of Economic Literature, 33: 13.47.

48 THROOP, A.W. (1993) "A Generalized Uncovered Interest Parity Model of Exchange Rates", FRBSF Economic Review, 2: 2-16.

49 WILlIAMSON, J. (1994) Estimating Equilibrium Exchange Rates. Institute for International Economics, Washington. 